\title{
Does Digitalization Increase Economic Growth? Evidence from ASEAN8 Countries ${ }^{\star}$
}

\author{
Dewa Gede Sidan Raeskyesa ${ }^{\mathrm{a}, *}$, \& Erica Novianti Lukas ${ }^{\mathrm{a}}$ \\ ${ }^{a}$ Universitas Prasetiya Mulya
}

\begin{abstract}
Digitalization has become relevant nowadays, not only because of the exposure of new technologies but also the consideration of its impact on the economy. In that regard, this study aims to analyze the effect of digitalization on economic growth. This study uses a descriptive analysis of the eight ASEAN middle-income countries from 1999 to 2014 as well as panel regression analysis with the dependent variable of GDP per capita growth and independent variables of physical capital, human capital, and ICT indicators. As a result, ICT indicators have a significant positive impact on economic growth, along with physical and human capital. The usage and intensity of ICT have a higher impact than access to ICT. Furthermore, human capital contributes the most among the other variables. We recommend the countries invest more in human capital to utilize ICT because it is the quality of human capital that matters to navigate the era of the digital economy.
\end{abstract}

Keywords: digitalization; ICT; economic growth; GDP per capita; ASEAN JEL Classification: O30; O15

\footnotetext{
${ }^{\star}$ We thank Calista Michelle Prima Wibowo for the excellent research assistance.

${ }^{*}$ Corresponding Author: Jln. BSD Raya Barat I, Kavling Edu I No. 1 BSD City, Serpong Tangerang 15339. E-mail: dewa.sidan@pmbs.ac.id.
} 


\section{Introduction}

Nowadays, the process of digitalization in our economy has gained significant interest from the academic realm to policymakers. The attention has been increased not only caused by the exposure of new technologies such as Artificial Intelligence and Big Data but also the consideration that the digitization will have an impact on our economy and society (Heimerl \& Raza, 2018).

Despite various meanings for the concept of the digital economy, several works are connected to the importance of this study. As summarized by Bukht and Heeks (2017), it is Mesenbourg (2001) who argues that the digital economy is about the provision of ICT infrastructure and when ICT becomes means in economic activities and business processes. Along with that, the Economist Intelligence Unit (2010) has used both the quality of countries' ICT infrastructure and the capability of the economic agents such as consumers, businesses, and governments to utilize ICT as indicators. As a result, we may define the digital economy as "[...] part of economic output derived solely or primarily from digital technologies with a business model based on digital goods or services." (Bukht \& Heeks, 2017: 4-14).

Moreover, as the digital economy is regularly reconstructed, the way we work and live through the capability of information, communication, and technology (ICT) innovations to transform the way both society and individuals interact with each other. However, the question of whether the existence of ICT will increase economic growth and productivity remains essential to be analyzed (Ahmad \& Schreyer, 2016).

At first, there were researchers who found indications that ICT has a negative effect on economic growth. For example, Pohjola (2002), who studied 42 countries within the 1985-1999 period of time, has found no significant relationship between ICT investment and economic growth (Pohjola, 2002). In the other study, Jacobsen (2003) argues that there is a negative relationship between telecommunication provisions on economic growth from 84 countries in the period 1990-1999 (Jacobsen, 2003). Specifically, in Japan, ICT investment does not lead to economic growth enhancement, despite its capability to lower energy consumption (Ishida, 2015). Furthermore, in a critical way, Niebel (2018) had questioned the impact of ICT investment on economic growth, as his study found no clear statistical sign that developing and emerging countries are receiving more benefits than developed countries (Niebel, 2018).

On the other hand, Ahmed and Ridzuan (2012) studied the relationship between ICT and economic growth in Indonesia, Singapore, Malaysia, Thailand, Philippines, Japan, Korea, and China (ASEAN+3). Panel data and Generalized Least Square (GLS) in the econometric analysis had been used, and they found that investment in telecommunications has a positive and long-run relationship with Growth Domestic Product (GDP). The study would be beneficial for policymakers in order to take investment in ICT as a consideration. Along with this study, Rath and Hermawan (2019), who specialized in their study on Indone- 


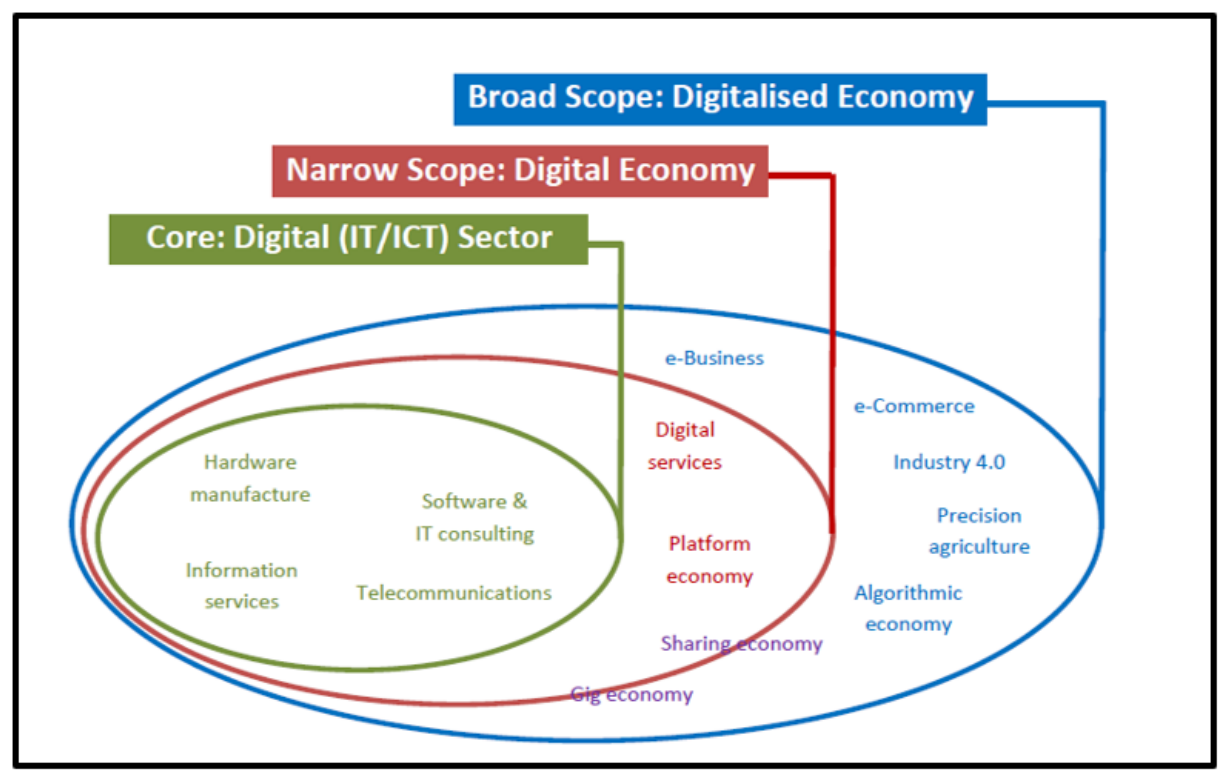

Figure 1: Digital Economy Scope

Source: Bukht and Heeks (2017:13)

sia had found that ICT development has a positive and significant relationship towards economic growth, both in the short and long run (Ahmed \& Ridzuan, 2012).

Then, Farhadi et al. (2012) studied the impact of ICT usage on economic growth in 159 countries from the period 2000 to 2009. They have used GDP per capita as a dependent variable and ICT index, which consists of the number of internet users, fixed broadband internet subscribers, and the number of mobile subscriptions per 100 inhabitants as the independent variable. They have found that there is a positive and significant effect on GDP per capita, especially in high-income countries, with a coefficient of up to 0.11 . However, the low-income countries showed profound effect with coefficient 0.02 (Farhadi et al., 2012).

While, in the European Union (EU) countries, Toader et al. (2018) had identified the effect of ICT usage on economic growth. Using panel data estimation and GDP per capita as the dependent variable, they found that ICT infrastructure has positive and strongly significant. An increase of 1 percent of ICT infrastructure usage would generate growth on GDP per capita between 0.0767 percent (fixedbroadband subscriptions) and 0.396 percent (mobile cell subscriptions) (Toader et al., 2018).

Moreover, Bahrini and Qaffas (2019) had studied the impact of ICT on economic growth in developing countries from the Middle East and North Africa (MENA) and Sub-Saharan Africa (SSA) region by using a panel Generalized 
Method of Moment (GMM) growth model in the period between 2007 and 2016. They found that the existence of mobile telephones has a positive effect on economic growth. However, mobile telephones have a greater and significant effect in countries from the SSA region and have replaced the fixed telephones lines usage. The other variables, such as internet usage and fixed broadband subscriptions per 100 inhabitants, also have a positive and significant impact on economic growth. Thus, their study confirms that internet usage may be a tool for innovation for better economic growth and suggest an enhancement in ICT infrastructure that benefit for mobile phone and internet application (Bahrini \& Qaffas, 2019).

In another study based on a group of countries, Pohjola (2000) uses a cross country analysis to find a strong impact between investments in information technology and economic growth in OECD countries (Pohjola, 2000). Moreover, Nasab and Aghaei (2009) studied the impact of ICT provision on economic growth in OPEC member countries. With panel data over the 1990-2007 period of time and use Generalized Method of Moment (GMM), they found that a 10 percent increase in ICT investment would increase the average GDP per capita up to 0.2 percent. As a result, they have concluded that the government of OPEC member countries should both increase the ICT infrastructure provision and education for the people on ICT utilization to enhance their economic growth (Nasab \& Aghaei, 2009).

Amongst the literature provided, our study will fill the gap by focusing on the impact of ICT investment on economic growth exclusively in middle-income countries within the ASEAN region.

\section{Research Methodology}

This study uses descriptive analysis of secondary data as well as quantitative analysis panel regression analysis with the dependent variable of GDP per capita growth and independent variables of physical capital, human capital, and ICT indicators. The key independent variables are the ICT indicators, which are divided into three categories: access, use, and skills (ITU, 2014).

\subsection{Key Independent Variables}

The access indicators that represent the ICT readiness can be captured from the proxies below:

- Fixed-telephone subscriptions/100 inhabitants

- Mobile-cellular telephone subscriptions/100 inhabitants

- International Internet bandwidth (bits/s) per user

- Percentage of households with a computer

- Percentage of households with Internet access 
The usage indicators that represent the ICT intensity can be captured from the proxies below:

- Percentage of individuals using the Internet

- Fixed (wired)-broadband subscriptions per 100 inhabitants

- Wireless broadband subscriptions per 100 inhabitants (includes the satellite, terrestrial fixed, and active mobile with a minimum download of $256 \mathrm{kbit} / \mathrm{s}$ )

The skills indicators that represent the ICT capability can be captured from the proxies below:

- Adult literacy rate (percentage of population 15 years old and older who can read and write simple statements with understanding and do simple arithmetic calculations)

- Gross enrollment ratio secondary level (total enrollment at a specific level of education as a percentage of all eligible)

- Gross enrollment ratio tertiary level (total enrollment at a particular level of education as a percentage of all eligible)

\subsection{Data}

We use secondary data of the eight ASEAN middle-income countries from 1999 to 2014. The states are as follows: Indonesia, Myanmar, Malaysia, Thailand, Vietnam, Cambodia, Lao PDR, and the Philippines (ASEAN8). The data was taken from Penn World Table 9.0 and World Development Indicators, World Bank.

\section{Results and Discussion}

\subsection{Descriptive Statistics}

The descriptive statistics of the variables are as follows:

Table 1: Descriptive Statistics of the Variables

\begin{tabular}{|c|c|c|c|c|c|}
\hline Variable | & Obs & Mean & Std. Dev. & Min & $\operatorname{Max}$ \\
\hline rgdpnacap | & 128 & 6727.131 & 5140.687 & 1149.078 & 21737.13 \\
\hline rkna | & 128 & 2003835 & 2998299 & 27886.9 & $1.32 e+07$ \\
\hline lgdpcap | & 128 & 8.539789 & .7493157 & 7.046715 & 9.986777 \\
\hline lhe | & 128 & .7573669 & .2002798 & .4053138 & 1.08809 \\
\hline $\operatorname{lpc} \mid$ & 128 & 13.22387 & 1.880099 & 10.23591 & 16.39503 \\
\hline Icellsubp | & 128 & 2.768372 & 2.158901 & -3.688516 & 5.001475 \\
\hline Iindintpop | & 127 & 1.193804 & 2.517904 & -8.793547 & 4.18662 \\
\hline
\end{tabular}

Table 1 provides the basic descriptive statistics for all the variables used. There is a quite wide dispersion regarding the level of GDP per capita (rdgdpnacap): the lowest GDP per capita was US\$1149.078 for Myanmar in 1999, whereas the highest one was US\$21737.13 for Malaysia in 2014. Moreover, the least level 
from the changes in growth per capita is 7.046715 percent for Myanmar in 1999, while the most considerable changes were 9.986777 percent for Malaysia in 2014. Then, the country with the highest progress in the level of human capital (lhc) is Malaysia in 2014 with 1.08809 percent, while Myanmar has the lowest index level in 1999 with 0.4053138 percent. Furthermore, the most significant changes in capital stock (lpc) up to 16.39503 percent was experienced by Indonesia in 2014, while the least one was Myanmar with 10.23591 percent in 1999.

In proxies for ICT access and usage, we have noticed that there is a vast difference between the countries one to another. It is ranged from -3.688516 percent (Myanmar, 1999) to 5.001475 percent (Malaysia, 2014) for the changes in mobile-cellular telephone subscriptions per 100 people. On the other side, the changes in the minimum level of percentage of individuals using the Internet were registered in Myanmar with -8.793547 percent in 1999, whereas the highest level was recorded in Malaysia with 4.18662 percent in 2012.

\subsection{Regression Results}

The results of panel regression using random effect are as follows:

Table 2: Regression Result

\begin{tabular}{|c|c|c|c|c|c|}
\hline \multirow{2}{*}{\multicolumn{4}{|c|}{$\begin{array}{l}\text { Random-effects GLS regression } \\
\text { Group variable: countryid }\end{array}$}} & Number of obs & 127 \\
\hline & & & & Number of groups & $=$ \\
\hline \multicolumn{4}{|l|}{$\mathrm{R}-\mathrm{sq}:$} & \multicolumn{2}{|l|}{ Obs per group: } \\
\hline \multicolumn{4}{|c|}{ within $=0.9626$} & $\min =$ & $=$ \\
\hline between = & 0.6879 & & & $\operatorname{avg}=$ & 15.9 \\
\hline overall = & 0.7112 & & & $\max =$ & $=$ \\
\hline $\operatorname{corr}\left(u_{-} i, \quad x\right)$ & \multicolumn{2}{|c|}{$=0 \quad$ (assumed) } & & Wald chi2(4) & $\begin{array}{r}3009.14 \\
0.0000\end{array}$ \\
\hline lgdpcap | & Coef. & Std. Err. & z & [95\% Conf. & - Interval] \\
\hline Ihe | & .9196907 & .1850333 & 4.97 & .5570322 & 1.282349 \\
\hline lpc | & .28868 & .0345849 & 8.35 & .2208948 & .3564651 \\
\hline lcellsubp | & .0152359 & .0082536 & 1.85 & -.0009409 & .0314126 \\
\hline lindintpop | & .0384078 & .0075968 & 5.06 & .0235184 & .0532973 \\
\hline _cons | & 3.94106 & .455702 & 8.65 & 3.0479 & 4.834219 \\
\hline sigma_u | & .52840457 & & & & \\
\hline sigma_e | & .05016599 & & & & \\
\hline rho | & .99106718 & (fraction & varia & ce due to u_i) & \\
\hline
\end{tabular}

After we did several tests such as the Hausman test and Breusch-Pagan Lagrange multiplier or well-known as LM test, the test result has directed us to use the random-effects GLS regression model. Based on this model, we have 
found all the independent variables are significant with a 1 percent standard error, unless for the mobile cellular telephone.

Human capital gives a positive and highly significant impact to growth by having a coefficient equal to 0.91 , which means when the countries improve their level in human capital will lead to an increase in economic growth per capita up to 0.91 percent. Moreover, the capital stock in the form of physical capital from the country of origin remains essential for economic growth. Similar result with the human capital index, the coefficient of physical capital is up to 0.28 with a positive and significant relationship. Therefore, when the countries manage to enhance their capital stock, there will be an increase of up to 0.28 percent on their GDP per capita.

In the context of ICT use indicators, mobile-cellular telephone subscriptions give positive and significant at the 10 percent level. The coefficient is equal to 0.015, which means when the countries increase their penetration on mobilecellular telephone usage, it will improve the growth per capita up to 0.015 percent. On the other hand, the internet seems to have more impact than the mobile-cellular telephone to economic growth. It shows that the variable of the percentage from individuals using the internet has positive and meaningful significance at the 1 percent level. Based on the coefficient values, the countries will increase their GDP per capita up to 0.038 percent when they foster internet penetration amongst society.

\subsection{Discussion}

As we can see, the empirical results show how human capital and physical capital or capital stock becomes the focal point for better GDP per capita; this result is consistent with the research from Lukas and Kadarusman (2014). Moreover, in this study, human capital gives the highest impact with meaningful significance amongst the other variables.

Based on Figure 2, we could see that Malaysia has an increasing trend, its human capital level, by reaching up to 2.97 points in 2014. This trend also experienced by Thailand, Vietnam, and the Philippine. However, from 2.40 points in 2010, Indonesia seemed to decline with 2.36 points in 2014. Furthermore, when we observe with other measurements such as Human Development Index from United Nations Development Program (UNDP), Malaysia remains in first place with 0.80 points in 2017, while Indonesia took fourth place with 0.69 points.

On the other side, ICT indicators such as the percentage of individuals using the internet gives a higher and strong significant impact on GDP per capita. In other words, the intensity and usage of ICT provide higher benefits to individual welfare than sole access to ICT. As the internet would enable knowledge to be distributed across individuals, the role of the internet becomes significant and positive on economic growth (Choi \& Yi, 2009). 


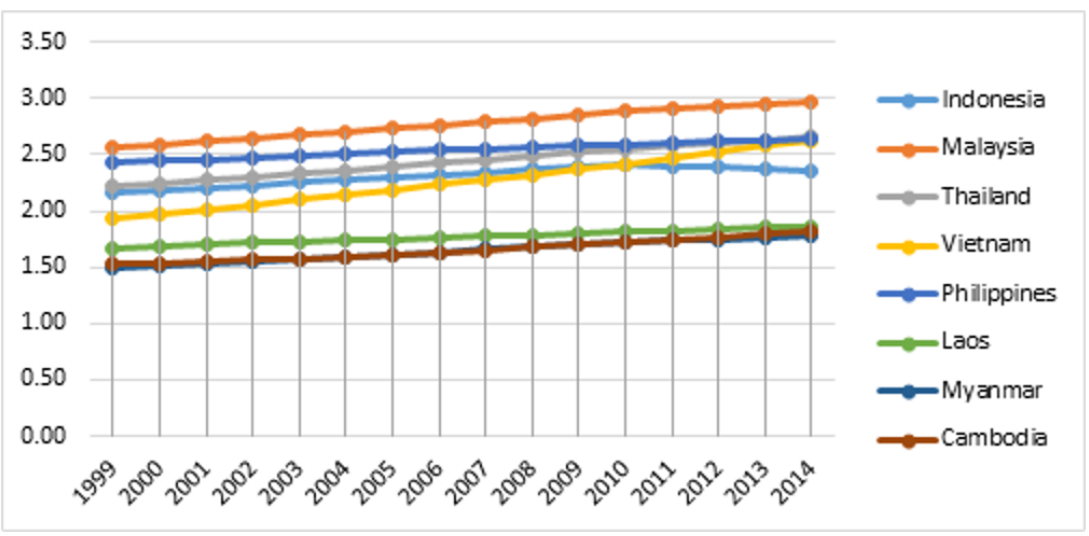

Figure 2: Human Capital Level in ASEAN8 Countries

Source: Feenstra et al. (2015)

Table 3: Human Development Index in ASEAN8 Countries

\begin{tabular}{lc}
\hline Country & HDI (UNDP - 2017) \\
\hline Malaysia & 0,802 \\
Thailand & 0,755 \\
Philippines & 0,699 \\
Indonesia & 0,694 \\
Vietnam & 0,694 \\
Laos & 0,601 \\
Cambodia & 0,582 \\
Myanmar & 0,578 \\
\hline Source: UNDP (2018)
\end{tabular}

From Figure 3, we can see the internet penetration from eight countries in ASEAN. With the increasing trend, Malaysia has been at first placed with more than 80 percent of its population using the internet. Then, Vietnam stood at second place with 70.35 percent, Thailand with 56,82 percent and Indonesia with 39,79 percent in 2018.

Therefore, from all these results, we may argue that the importance of rising human capital and ICT usage would give higher benefits than just infrastructure provision. One of many reasons is because decent human capital enables to utilize the technological knowledge that matters for productivity enhancement (Tezcan, 2006). In this study, we have seen from descriptive information on how Malaysia with the highest GDP per capita has been placed in the first place for most of the categories, from human capital to ICT usage indicator.

Moreover, as education could be one of the ways to form the human capital (Wibowo, 2018), it would be beneficial to foster education activities to enhance the capability to utilize ICT and the Internet for useful purpose in society or what is known as 'digital literacy.' Nowadays, digital literacy becomes an essential factor 


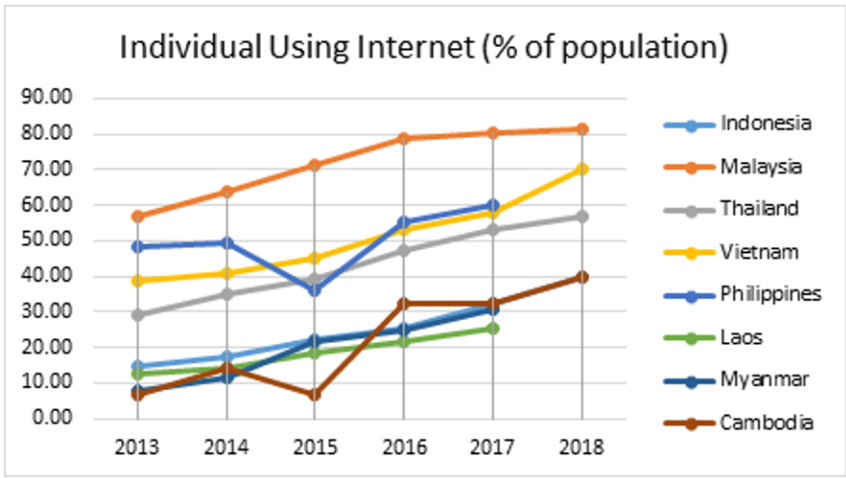

Figure 3: ASEAN8 Countries' Percentage of Individual Using Internet Source: World Development Indicators

Table 4: ASEAN8 Countries' GDP per capita in 2018

\begin{tabular}{lc}
\hline \multicolumn{2}{c}{ ASEAN GDP per capita in 2018 } \\
\hline Country & GDP per capita (USD) \\
\hline Malaysia & 10941,745 \\
Thailand & 7187,193 \\
Indonesia & 3870,562 \\
Philippines & 3103,62 \\
Vietnam & 2551,123 \\
Cambodia & 1508,817 \\
Myanmar & 1297,679 \\
\hline Source: International Monetary Fund
\end{tabular}

for creativity, innovation, and entrepreneurship activities (Martin, 2005). Thus, promoting digital literacy in higher education institutions would be a valuable action, primarily due to the fact that many students enter the university already have a high level of exposure to digital technologies and media (Santos \& Serpa, 2017).

\section{Conclusion and Recommendation}

Based on the empirical results, we have concluded that the digital aspect in our economy through appointed ICT indicators gives a positive and significant impact to GDP per capita after other variables such as capital stock and human capital. Moreover, it is clear that providing access to ICTs on its own is not enough to utilize the benefit of ICT usage for increasing GDP per capita. We need more than just access, which leads us to develop our human capital. As Stiglitz (2013) expresses that human is the most essential capital in the economy.

Furthermore, it would be beneficial for the countries, especially the Indonesian government to invest more in human capital through education and training 
to utilize ICT's benefit for better welfare, as Gary Becker said: "Education and training are the most important investments in human capital." (Becker, 1992, p.85). It is our quality of human capital that matters to navigate the era of the digital economy.

\section{References}

[1] Ahmad, N., \& Schreyer, P. (2016). Are GDP and productivity measures up to the challenges of the digital economy?. International Productivity Monitor, (30), 4-27. Retrieved from http://www.csls.ca/ipm/30/ahmadandschreyer.pdf.

[2] Ahmed, E. M., \& Ridzuan, R. (2013). The impact of ICT on East Asian economic growth: panel estimation approach. Journal of the Knowledge Economy, 4(4), 540-555. doi: https://doi.org/10.1007/s13132-012-0096-5.

[3] Bahrini, R., \& Qaffas, A. A. (2019). Impact of information and communication technology on economic growth: Evidence from developing countries. Economies, 7(1), 21. doi: https://doi.org/10.3390/economies7010021.

[4] Becker, G. S. (1992). Human capital and the economy. Proceedings of the American Philosophical Society, 136(1), 85-92.

[5] Bukht, R., \& Heeks, R. (2017). Defining, conceptualising and measuring the digital economy. Development Informatics Working Paper, 68. Centre for Development Informatics Global Development Institute, SEED - University of Manchester. Retrieved from https://diodeweb.files.wordpress.com/2017/08/diwkppr68-diode.pdf.

[6] Choi, C., \& Yi, M. H. (2009). The effect of the internet on economic growth: Evidence from cross-country panel data. Economics Letters, 105(1), 39-41. doi: https://doi.org/10.1016/j.econlet.2009.03.028.

[7] Economist Intelligence Unit. (2010). Digital Economy Rankings 2010 Beyond EReadiness: A report from the Economist Intelligence Unit. The Economist Group. Retrieved from https://graphics.eiu.com/upload/EIU_Digital_economy_rankings_ 2010_FINAL_WEB.pdf.

[8] Farhadi, M., Ismail, R., \& Fooladi, M. (2012). Information and communication technology use and economic growth. PloS one, 7(11), e48903. doi: 10.1371/journal.pone.0048903.

[9] Feenstra, R. C., Inklaar, R., \& Timmer, M. P. (2015). The next generation of the Penn World Table. American Economic Review, 105(10), 3150-3182. doi: 10.1257/aer.20130954.

[10] International Monetary Fund. (n.d.). Real GDP growth: Annual percent change. Retrieved from https://www.imf.org/external/datamapper/NGDP_RPCH@WEO/ OEMDC/ADVEC/WEOWORLD.

[11] Heimerl, V., \& Raza, W. (2018). Digitalization and Development Cooperation: an assessment of the debate and its implications for policy. Briefing Paper, 19. Austrian Foundation for Development Research. Retrieved from https://www.oefse.at/fileadmin/content/Downloads/Publikationen/ Briefingpaper/BP19-Digitalization-and-Development.pdf.

[12] Ishida, H. (2015). The effect of ICT development on economic growth and energy consumption in Japan. Telematics and Informatics, 32(1), 79-88. doi: https://doi.org/10.1016/j.tele.2014.04.003.

[13] ITU. (2014). Measuring the information society report 2014. International Telecommu- 
nication Union. Retrieved from https:/ /www.itu.int/en/ITU-D/Statistics/Pages/ publications/mis2014.aspx.

[14] Jacobsen, K. F. L. (2003). Telecommunications - a means to economic growth in developing countries?. Research report R 2003: 13. Chr. Michelsen Institute. Retrieved from https:/ /open.cmi.no/cmi-xmlui/handle/11250/2436122.

[15] Lukas, E. N., \& Kadarusman, Y. (2014). Middle income trap di Indonesia: Faktor penentu dan strategi menghindarinya. Prosiding seminar nasional \& sidang pleno ISEI XVI: Pembaharuan institusi ekonomi dan mutu modal manusia (pp. 138-148). Ikatan Sarjana Ekonomi Indonesia.

[16] Martin, A. (2005). DigEuLit-a European framework for digital literacy: a progress report. Journal of eLiteracy, 2(2), 130-136.

[17] Mesenbourg, T. L. (2001). Measuring the digital economy. E-Stats Working Papers. United States Census Bureau. Retrieved from https:/ /www.census.gov/library/ working-papers/2001/econ/mesenbourg-01.html.

[18] Nasab, E. H., \& Aghaei, M. (2009). The effect of ICT on economic growth: Further evidence. International Bulletin of Business Administration, 5(2), 46-56.

[19] Niebel, T. (2018). ICT and economic growth-Comparing developing, emerging and developed countries. World Development, 104, 197-211. doi: https://doi.org/10.1016/j.worlddev.2017.11.024.

[20] Pohjola, M. (2000). Information technology and economic growth: a cross-country analysis. WIDER Working Paper 173/2000. United Nations University World Institute for Development Economics Research (UNU-WIDER). Retrieved from https:/ / www. wider.unu.edu/publication/information-technology-and-economic-growth.

[21] Pohjola, M. (2002). The new economy in growth and development. Oxford Review of Economic Policy, 18(3), 380-396. doi: https://doi.org/10.1093/oxrep/18.3.380.

[22] Rath, B. N., \& Hermawan, D. (2019). Do information and communication technologies foster economic growth in Indonesia?. Buletin Ekonomi Moneter dan Perbankan, 22(1), 103-122. doi: https://doi.org/10.21098/bemp.v22i1.1041.

[23] Santos, A. I., \& Serpa, S. (2017). The Importance of Promoting Digital Literacy in Higher Education. International Journal of Social Science Studies, 5(6), 90-93. doi: https://doi.org/10.11114/ijsss.v5i6.2330.

[24] Stiglitz, J. (2013). The price of inequality: How today's divided society endangers our future. WW Norton \& Company.

[25] Tezcan, M. (2006). The role of education and ICT in economy. In International Conference on Human and Economic Resources Proceedings Book (pp. 338-344). Izmir University of Economics \& Suny Cortland. Retrieved from https:/ / eco.ieu.edu.tr/wp-content/ proceedings/2006/2006.pdf.

[26] Toader, E., Firtescu, B. N., Roman, A., \& Anton, S. G. (2018). Impact of information and communication technology infrastructure on economic growth: An empirical assessment for the EU countries. Sustainability, 10(10), 3750. doi: https://doi.org/10.3390/su10103750.

[27] UNDP. (2018). Human Development Indices and Indicators: 2018 Statistical Updates. United Nations Development Programme. Retrieved from http://hdr.undp.org/ sites/default/files/2018_human_development_statistical_update.pdf.

[28] Wibowo, M. G. (2018). Perkembangan dan persaingan modal manusia (human capital) Indonesia dan negara-negara ASEAN serta kaitannya dengan kesejahteraan. Prosiding Seminar Nasional \& Kongres ISEI XX (pp. 27-36). Ikatan Sarjana Ekonomi Indonesia. 
[29] World Bank. (n.d.). World Development Indicator. Retrieved from http://datatopics. worldbank.org/world-development-indicators/. 